\title{
Preliminary Expectoration
}

For scholars of Black Studies-and we use the aforesaid term in its broadest and most inclusive sense-who have pursued a life-of-the-mind in the field for the past three decades or more, the haunting question—Does it matter? — however fleeting, yearns for deep reflection and musing.

For Black Studies, often pejoratively billed as "particularistic" by so-called universalists and their pubescent acolytes, whose practitioners' prestige and department and /or programs' institutional states have historically been comparatively low, the practitioner's quest for the field's raison d'etre and meaning might seem elusive.

Practitioners of Black Studies might perhaps take some solace in the practical and somewhat cynical stance that their endeavors helped pay the bills. Yet, when one has been at some point or another engaged deeply with his or her students, institutions, and disciplines, there might exist the lingering feeling that one's efforts were not in vain.

It is with the aforesaid in mind that the emergence of the nexus of Black Studies with Diasporic Studies comes as a hopeful sign for those entrapped in a lonely labyrinth. Thus, in this short—not to say intellectually bogus—inaugural issue, the co-editors have solicited from members of our distinguished editorial board brief commentaries on the significance of Black Diasporic Studies for the traditional discipline in which they were trained. The three commentaries represent the reflections of seasoned scholars from two of the Big Ten's landgrant institutions: The Pennsylvania State University and Purdue University.

The co-editors have taken the liberty of rendering a relationship between these seemingly disparate commentaries in the following manner: the idea that Black people outside of Africa respond, at least to some extent, to what the philosopher Leonard Harris calls a "common oppression," makes us cautiously optimistic about the possibility of enhancing the degree of Black agency that scholars, such as the social scientist James B. Stewart, view as the guiding mission of Black Studies. Nevertheless, as the literary scholar Antonio D. Tillis demonstrates through the exhumation of key authors in Afro-Latin American literature, the current inclusion of these figures in the canon of Hispanic-American literature also expands the "geospatial and geopolitical voices" of Black Studies, thereby highlighting the ethnic or cultural diversity of the field. In essence, what we envision is often the jettisoning of the noxious and divisive notions of African-American exceptionalism, and, in so doing, engendering an inclusive and ecumenical Black Diaspora Studies.

The review essays herein written by two of our excellent M.A. students in the Department of African American and African Diaspora Studies here at Indiana University, Bloomington constitute a convincing effort to highlight some of the major publications of the past thirty-odd years that facilitate the connection between Black Studies and Native American Studies and Black Studies and Gender Studies.

That said, we welcome all contributions to our journal in the coming years.

Vernon J. Williams, Jr. Frederick L. McElroy 